\title{
Dendrochronological dating of coal mine workings at the Joggins Fossil Cliffs, Nova Scotia, Canada
}

\author{
Sarah L. Quann ${ }^{1, *}$, Amanda B. Young ${ }^{1}$, Colin P. Laroque ${ }^{1}$, \\ Howard J. Falcon-Lang ${ }^{2}$ and Martin R. Gibling ${ }^{3}$ \\ 1. Mount Allison Dendrochronology Laboratory, Mount Allison University, 144 Main Street, Sackville, \\ New Brunswick E4L 1A7, Canada \\ 2. Department of Earth Sciences, Royal Holloway, University of London, Egham, Surrey TW20 0EX, United Kingdom \\ 3. Department of Earth Sciences, Dalhousie University, Halifax, Nova Scotia B3H 4J1, Canada \\ *Corresponding author <slquann@mta.ca>
}

Date received 4 May 2010 S Date accepted 19 November 2010

\begin{abstract}
Joggins, Nova Scotia, was one of the first places in North America where coal was mined. Dendrochronological methods were employed to date timber pit props preserved within relic coal mine workings on the closely adjacent Fundy and Dirty seams. These remains comprise a system of "openings" that represent formerly underground mines, now exposed by cliff retreat. Of the seventy-three samples collected, forty-eight were successfully cross-dated into floating chronologies and then compared against a local red spruce (Picea rubens) master chronology, thereby establishing the year in which each individual sample was cut as a live tree where bark was present. Results indicate cutting dates of 1849-1875, which are generally consistent with archival records of mining activity. Analysis of the 14 openings allows differentiation of two phases of mining. Most openings (1-9 and 11-12 with cut dates of 1849-1868) represent "adits" driven into the cliff from the beach, and associated "levels", which comprise an initial drift mine by the General Mining Association (1865-1871). Dendrochronological dates from trees with bark that precede the opening of this first mine suggest that timber stockpiled from the nearby Joggins Mine (opened 1847) was used in its construction. The remaining openings (10 and 13-14 with cut dates of 1873-1875) represent a system of "levels" that comprise part of a later mine dug by the Joggins Coal Mining Company (1872-1877). Findings improve knowledge of the Joggins UNESCO World Heritage Site and help refine the regional chronology for future dendrochronological studies.
\end{abstract}

\section{RÉSUMÉ}

La localité de Joggins, en Nouvelle-Écosse, a été l'un des premiers endroits en Amérique du Nord d'où on a extrait du charbon. Des méthodes de dendrochronologie ont été utilisées pour établir l'âge des chandelles de bois d'oeuvre conservées dans les anciens ouvrages de mines de charbon des filons de charbon rapprochés de Fundy et Dirty. Ces vestiges se composent d'une série «d'ouvertures » qui correspondent à d'anciennes mines souterraines, que le recul des falaises a maintenant exposées. Parmi les 73 échantillons recueillis, il a été possible d'établir la datation par recoupement de 48 pièces et d'en déduire une chronologie variable, puis de comparer ces données en regard d'une chronologie générale d'épinette rouge (Picea rubens) de la région. Cet examen a ensuite permis de connaitre l'année au cours de laquelle chaque échantillon a été prélevé d'un arbre vivant sur lequel l'écorce était encore présente. Les résultats indiquent une période de coupe comprise entre les années 1849 et 1875, ce qui serait pour l'essentiel corroboré par les archives connues de l'activité minière dans la région. Une analyse des 14 ouvertures présentes permet par ailleurs de circonscrire deux périodes distinctes d'activité minière. Les échantillons de la plupart des ouvertures (1-9 et 11-12) ont une date de coupe qui se situe entre 1849 et 1868. Ces ouvertures sont des «galeries d'accès » creusées dans la falaise à partir de la plage et des «niveaux» connexes qui correspondent à une première exploitation minière à flanc de coteau par la General Mining Association (1865-1871). La périodisation dendrochronologique des arbres possédant encore de l'écorce et dont la datation est antérieure à l'aménagement de cette première mine porte à croire que des grumes de bois d'œuvre empilées à la mine Joggins toute proche (ouverte en 1847) ont servi aux travaux de construction de la mine. Les autres ouvertures (10 et 13-14, dont la période de coupe des échantillons se situerait entre 1873 et 1875) correspondent à une série de «niveaux» d'une mine aménagée ultérieurement par la Joggins Coal Mining Company (1872-1877). Ces observations viennent enrichir les connaissances que nous possédons sur le Site du patrimoine mondial de l'UNESCO de Joggins et elles nous aideront à mieux préciser la chronologie régionale aux fins de futures études dendrochronologiques.

[Traduit par la redaction] 


\section{INTRODUCTION}

The Joggins Fossil Cliffs of Nova Scotia, Canada, are one of the world's most famous fossil sites (Falcon-Lang et al. 2010). Awarded UNESCO World Heritage Status on 7 July 2008, these towering sea-cliffs along the Bay of Fundy have yielded a spectacular array of fossils from the Carboniferous "Coal Age", about 315 million years ago (Calder 1998; Falcon-Lang et al. 2006). Charles Lyell, the well-known Victorian geologist, was an early visitor in 1842 and 1852 . He documented upright fossil trees rooted in coal seams and early tetrapods; and later, Charles Darwin alluded to the importance of Joggins in his epoch-making Origin of Species (Calder 2006; Falcon-Lang 2006).

Less well known is that Joggins was one of the first places in North America where coal was mined (Falcon-Lang 2009). French settlers first exploited its coal in the late Seventeenth Century (Franquelin 1686), if not earlier, and the "Coal Cliffs" of Joggins quickly became a prominent feature on maps of North America (Moll 1730). Most early coal mines at Joggins supplied Boston, Massachusetts (Hale 1731), and at times the British and French squabbled over Joggins' sought-after resources (Knox et al. 1759). However, despite the strategic importance of coal, mining remained sporadic until the midNineteenth Century, when more systematic and larger scale exploitation commenced (Drummond 1918).

Timber pit props and associated structures protrude from the Joggins sea-cliffs at several locations today (Falcon-Lang 2009). These are the remains of formerly underground coal mine workings which have since been exposed by cliff retreat. Dawson (1882) estimated the rate of retreat to be $\sim 0.19 \mathrm{~m}$ per year for some parts of the section, based on 40 years of observation. So, several tens of metres of erosion may have occurred since mining commenced. However, although mine workings were first noticed eroding out of the cliff face in the early Twentieth Century (Bell 1913), their age has been much debated and remains uncertain. They may represent late Nineteenth Century mines or they may date from earlier periods of British or French occupation. In this paper, we employ dendrochronological analyses to ascertain the age of the best-exposed coal mine workings.

\section{STUDY AREA}

The Joggins Fossil Cliffs are located on the southeastern shore of Chignecto Bay, the northwestern arm of the Bay

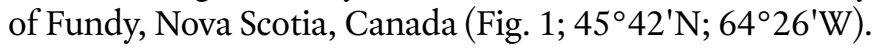
Along the 4-km-long cliff section between Lower Cove and McCarron's Creek, more than 100 coal seams crop out, but only seven attain economic thickness ( $>1 \mathrm{~m}$ thick) and have been mined extensively. From base to top, these are Coal 32 (unnamed), Coal 29A (Fundy, also known as Cumberland or Hardscrabble), Coal 29 (Dirty), Coal 20 (Forty Brine), Coal 14 (Kimberley), Coal 8 (Queen), and Coal 7 (Joggins seams, also known as King or Main), the numbers relating to the systems

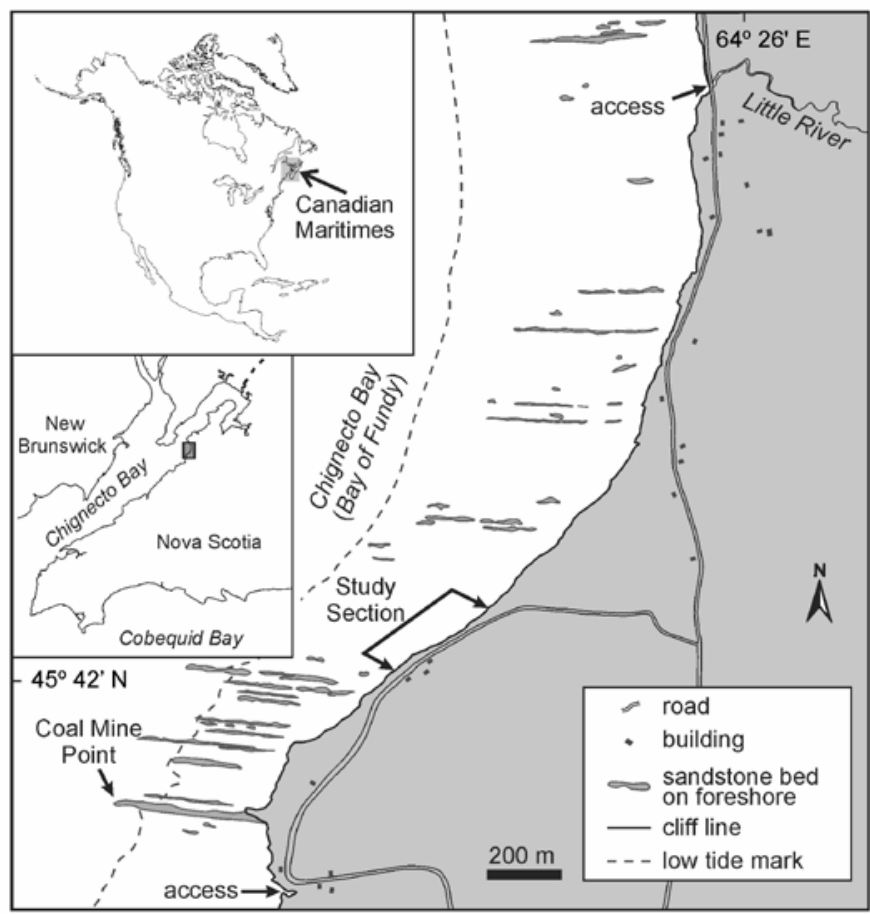

Fig 1. Location of the Joggins Fossil Cliffs study site on the Bay of Fundy coast near Joggins, Nova Scotia, Canada.

of Logan and Dawson (Currie 1942; Goudge 1945; Copeland 1959; Davies et al. 2005; Rygel and Shipley 2005; Calder et al. 2006). Coal mine workings, including timber pit props and other archaeological materials, occur on all of these seams, but are especially well exposed on the closely adjacent Fundy and Dirty seams (coals 29A and 29, respectively, as illustrated in Davies et al. 2005), which form the focus of this study.

The Fundy and Dirty seams crop out about $1.7 \mathrm{~km}$ south of Lower Cove. Here, the Fundy Seam is a 0.85 -m-thick bituminous coal (Hower et al. 2000), whereas the Dirty Seam, as its name suggests, is a 1.5 -m-thick clastic-rich (high ash) coal (Calder et al. 2006). Stratigraphically, the coals are positioned at $420 \mathrm{~m}$ and $428 \mathrm{~m}$, respectively, above the stratigraphic base of the Joggins Formation and dip at $21^{\circ}$ SSE (Davies et al. 2005). As a result of this inclination, the two coals delineate an outcrop zone extending between $45^{\circ} 42^{\prime} 14.34^{\prime \prime} \mathrm{N} ; 64^{\circ}$ $26^{\prime} 31.92^{\prime \prime} \mathrm{W}$, where the Fundy seam occurs at the cliff top, and $45^{\circ} 42^{\prime} 12.36^{\prime \prime} \mathrm{N} ; 64^{\circ} 26^{\prime} 36.90^{\prime \prime} \mathrm{W}$, where the Dirty Seam occurs at beach level, a horizontal distance of $\sim 150 \mathrm{~m}$ (Fig. 1).

\section{DESCRIPTION OF COAL MINE WORKINGS}

\section{Mining Terminology}

In this paper, we follow standard coal-mining terminology in common usage at the time that the mines on the Fundy and Dirty seams were active (Gresley 1883). We refer to three types 

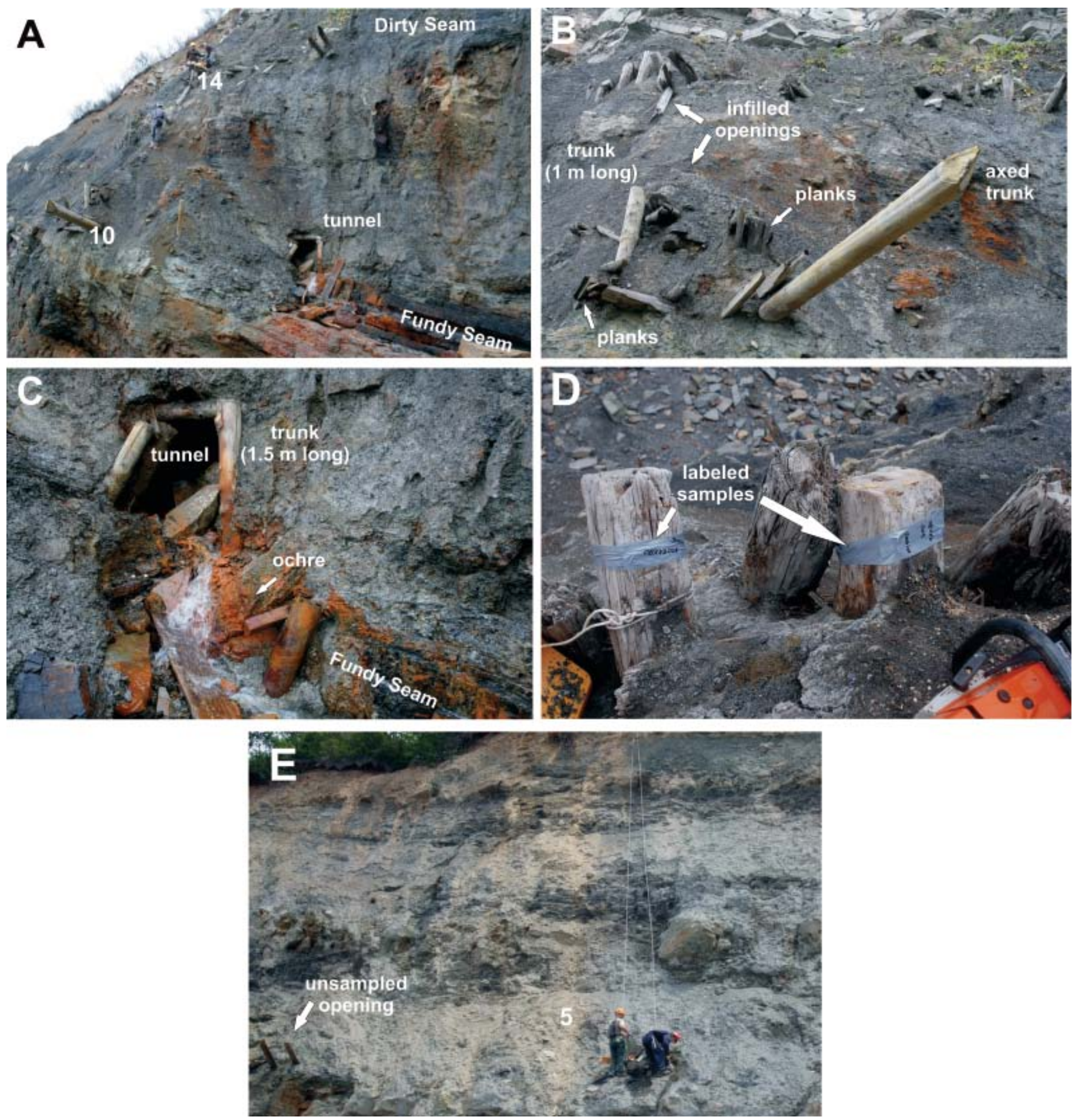

Fig. 2. Pit props associated with the Fundy and Dirty seams, Joggins. (A) Cliff view with trunk clusters 10 and 14 (see Fig. 3) and open adit on the Fundy seam. (B) Close up of cluster 10. (C) Close up of open adit at beach level, with stain of redbrown ochre (precipitated iron oxides and hydroxides) on wood and rock surfaces, derived from acid mine drainage. (D) Material at cluster 14 before being sampled. Each cluster was labelled, mapped, and photographed before samples were extracted for analysis. The photo shows unmodified and squared-off tree trunks of approximately 25 by $25 \mathrm{~cm}$ labelled and ready to be cut. (E) An example of the rope and anchor system used to belay team members downslope approximately 8 metres to access the exposed samples along the cliff. Team members are working on samples at cluster \#5, with projecting timber from other openings visible to their left. 


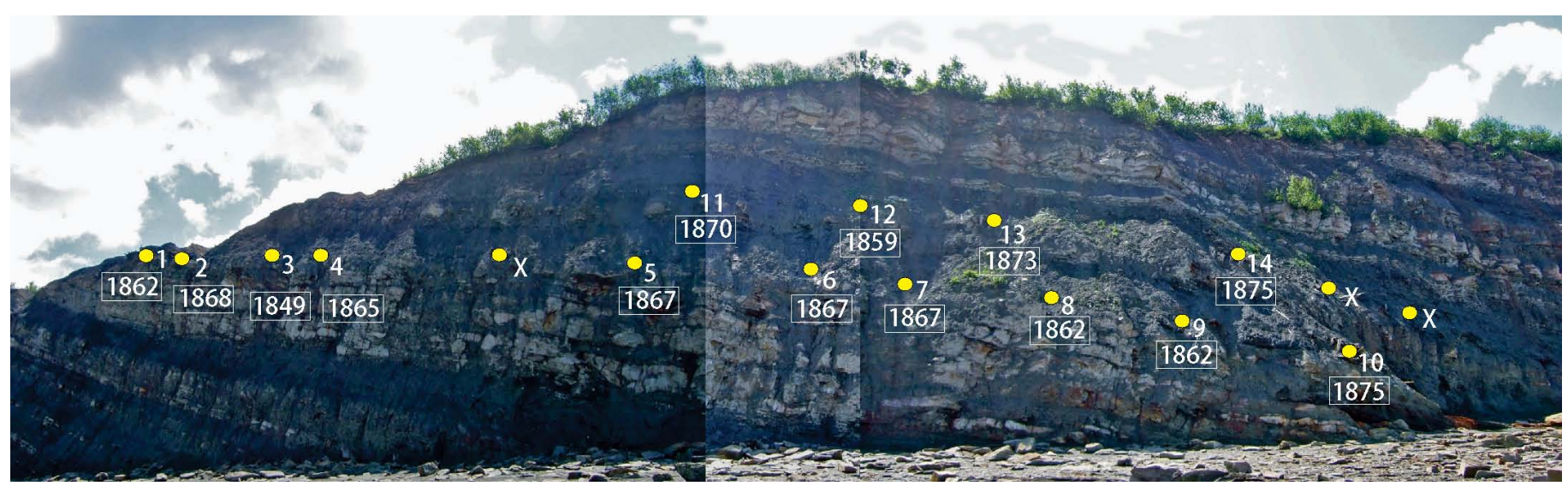

Fig. 3. A photomontage illustrating the entire exposure with the 14 clusters numbered and minimum cut dates of the exposed timber found for each cluster depicted. Areas marked " $X$ " represent clusters that were not sampled. The distance along the beach from cluster 1 to cluster 10 is approximately $120 \mathrm{~m}$.

of underground mines: (1) drift mines, connected horizontally to the surface; (2) shaft mines, connected to the surface by a vertical shaft; and (3) slope mines, connected to the surface by an inclined slope. We employ the general term "opening" to indicate any horizontal mine passageway in underground mines. However, where we are able to be more specific, we use the term "adit" for a type of opening whose entry was connected to the surface horizontally and the term "level" for an opening connected to the surface via a slope or a shaft.

\section{Observations}

The type and distribution of timber in the cliff face at the Joggins site was studied by direct observation where possible, and using binoculars for inaccessible examples higher in the cliff. On both coal seams, timber is distributed in distinct openings (Fig. 2A). Each opening is $\sim 2 \mathrm{~m}$ wide, $\sim 1$ to $1.5 \mathrm{~m}$ high, and separated from the next opening up-dip by a gap of $\sim 4$ to $7 \mathrm{~m}$. Each group of timbers marks the position of a system of openings arranged at regular intervals up-dip and trending ENE (along strike). Openings in the Fundy and Dirty seams do not directly overlie each other but are offset (Fig. 3), thus avoiding the possibility that an overlying opening might collapse into one below. Although loose debris covers most of the coal exposures, zones of unmined coal are visible locally between the openings, which are filled with rock material that probably fell in from the roof(Fig. 2B). The observed system of openings and slopes suggests that mining employed the "bord and pillar" technique, in which coal is extracted along horizontal levels, and pillars of coal are left in between to support the roof. One opening just above beach level, which has prominent ochre staining of wood and rock surfaces, differs from the others in that it remains open (not filled with debris), has a slightly different NNE trend, and appears to gently climb up-dip (Fig. 2C). We further discuss this feature below, and hereafter refer to it as "the tunnel".

Where well exposed and preserved, most openings are walled on either side by a timber palisade. This palisade com- prises vertically orientated tree trunks, typically 0.1 to $0.25 \mathrm{~m}$ in diameter, which were hand-sawn into 1 to $1.5 \mathrm{~m}$ lengths, thus broadly matching the thickness of the coal (Fig. 2). The trunks locally retain bark and show scars where lateral branches have been removed using an axe. In one opening, the palisade comprises squared-off tree trunks prepared at a sawmill (Fig. 2D), and one trunk has had its topmost part squared off, presumably to fit into a notch in a roof plank or trunk. Also present, but far less common, are timber boards, $<0.1 \mathrm{~m}$ thick, $0.3 \mathrm{~m}$ wide, and locally $>1 \mathrm{~m}$ long, which have been machinemilled. Although locally occurring in a jumbled mass, these boards are commonly flat-lying within the material that fills the openings (Fig. 2B). We infer that the function of the vertical palisade and flat-lying boards was to support the roof and minimize caving. Iron rail fragments have been found in these mine workings and in other workings nearby, for the passage of small coal trucks. We also observed one very long $(>3 \mathrm{~m})$ piece of tree-trunk, lying horizontally in an opening just above beach level, whose end had been axe-hewn into a spike (Fig. 2B). Its function is uncertain.

\section{METHODS}

To determine the age of these coal mine workings, we obtained samples for dendrochronological analysis. Sampling occurred during a preliminary investigation in November 2008 (samples MAD Lab 08BDD000) and a follow-up study in the summer of 2009 (samples MAD Lab 09ES000). Permission to sample at this protected UNESCO World Heritage Site was granted through Nova Scotia Museum Heritage Research Permits \#A2009NS50 and \#A2008NS94.

\section{Field Methods}

To obtain samples, crew members were belayed from the top of the cliff using a rope anchor system (Fig. 2E). Special attention was placed on safety, and all applicable protection 
was used in regards to ropes, harnesses, helmets, and eye protection. Once members arrived at the level of the mine workings, they were secured at that height, and all exposed timber samples were recorded and individually mapped. Samples that were selected for collection were numbered and labeled, and debris was removed from around them to assist in extraction (Fig. 2D). Cross-sections were then collected using a saw and sent back to the top of the cliff using a rope and bag system. A GPS point was taken above each cluster of timber, and all samples at a cluster were sketched on a site map.

Clusters of samples, approximating the position of individual openings, were numbered from the top of the cliff face to the bottom. Openings 1-10 occur on the Fundy Seam and Openings 11-14 on the overlying Dirty Seam (Fig. 3). Along with the 14 clusters sampled, additional isolated timbers were noted; these probably represent the remains of additional openings still buried and eroding to the surface.

\section{Laboratory Methods}

Samples were cut into 80-mm-thick discs using a band saw at the Mount Allison Dendrochronology Laboratory (MAD $\mathrm{Lab}$ ). They were then polished with progressively finer sandpaper (80-400 grit) to improve clarity of the tracheids and make the tree rings clearer and more easily distinguishable. Samples were visually assessed to make sure they contained similar radial-growth patterns, and then the tree-ring sequence for each sample was measured on two paths across the most structurally sound portions of the disc (Stokes and Smiley 1968). The two paths were at an angle greater than $90^{\circ}$ to each other in order to maximize the variance captured in the ring patterns.

Ring sequences were measured using a Velmex measuring system attached to a 63X Nikon SMZ800 microscope. The system measures the distance between each annual ring boundary (accurate to $0.001 \mathrm{~mm}$ ) and additionally allows the number of rings in each sample to be determined. The undated ring sequence is assigned preliminary nominal dating for each sample. In addition, the cellular characteristics of each sample were also noted under the microscope in order to identify the tree species.

Cross-dating is a method of pattern matching a tree's growth signals of unknown age (floating chronology) to that of a known pattern that is locked in time (master chronology). Following the path measurements of the individual radii, each was first cross-dated into a within-seam floating chronology and then each floating chronology was matched against the regional red spruce master chronology. To assist in the cross-dating procedure the statistical cross-dating program COFECHA was used. COFECHA uses correlation values to assist in accurately dating the samples (Holmes 1983). The floating chronologies were input into COFECHA and compared to the pattern of a master chronology based on 50-year lagged segments. The master chronology is made up of 142 living (end date confirmed) and structurally derrived (cross-dated) samples that cover the interval between the years 1624 and 2006. In the cross-dating procedure, a correlation value is assigned to each sample based on how well it fits statistically against the master chronology. Higher correlation values indicate that the floating chronology corresponds well to the time period in the master chronology to which it was matched.

A visual comparison of the ring-width relationship against the master chronology was constructed using program ARSTAN (Cook 1985). Each of the floating and master chronologies was standardized to have a mean of one by using a negative exponential curve. This standardization was completed to remove the natural biological effects related to different ages of the samples compared. All samples were standardized using this method. Graphs containing these curves were created to observe and cross-validate the relationships between each sample beam, samples within a floating chronology and samples against the regional master chronology.

\section{RESULTS}

In total, 73 samples were collected. After microscopic observation of anatomical characteristics, 70 of these samples were determined to be red spruce (Picea rubens). These samples could eventually be compared with an existing regional master chronology for red spruce (MAD Lab archives), which spans the interval 1624 to 2006. Three samples (08BDD01, 09ES17, 09ES18) of white birch (Betula papyrifera) and balsam fir (Abies balsamea) were excluded from the analysis because no long regional master chronology for these taxa is available. A further 22 samples were also excluded from the analysis because they contained less than 30 tree rings. Short tree-ring sequences produced statistical uncertainty in their placement against a master chronology because they might fit into any number of time periods (Grissino-Mayer 2001). The remaining 48 samples qualified for the full analysis, having an average of 94 rings and a range of 33 to 247 rings.

From the Fundy Seam, 35 samples were analyzed and incorporated into a floating chronology from 10 separate openings (1-10). From the Dirty Seam, a further 13 samples were analyzed and incorporated into a floating chronology from 4 openings (11-14). The full dataset is given in Tables 1a and $1 b$, showing the number of tree-rings in each sample, the estimated cut date for each tree (i.e., the year it was felled, when bark is present), the significance level of correlation between the averaged two radii per sample to the master red-spruce chronology, and whether bark was present in the sample. Where the bark was not identified, estimated cut dates are minimum estimates, as tree-rings could have been removed from the outer part of the tree by decay or milling. However, this problem affected only 10 samples $(21 \%)$, so we have confidence in nearly all of the cut dates.

Results show a similar age profile for mine workings on both coal seams. The cutting dates for samples with bark on the Fundy Seam are 1849-1875 (mean correlation 0.387 to the master based on 50-year segments), and for the Dirty Seam they are 1856-1875 (mean correlation 0.445 to the master based on 50-year segments). The overall correlation of all 48 
Table 1a. Samples from the Fundy Seam cross-dated against the Mount Allison Dendrochronology Laboratory (MAD Lab) regional red spruce master chronology.

\begin{tabular}{|c|c|c|c|c|c|}
\hline $\begin{array}{l}\text { Opening } \\
\text { number }\end{array}$ & $\begin{array}{l}\text { Sample identification } \\
\text { code }\end{array}$ & $\begin{array}{l}\text { Number of } \\
\text { tree-rings }\end{array}$ & $\begin{array}{c}\text { Mean correlation to } \\
\text { the master } \\
\text { chronology }\end{array}$ & $\begin{array}{l}\text { Last year } \\
\text { of growth }\end{array}$ & $\begin{array}{c}\text { Presence of } \\
\text { bark }(Y=y e s, \\
\mathrm{N}=\mathrm{no})\end{array}$ \\
\hline 1 & 09ES5 & 50 & 0.256 & 1862 & $\mathrm{Y}$ \\
\hline 1 & 09ES6 & 44 & 0.314 & 1859 & $\mathrm{~N}$ \\
\hline 2 & 09ES9 & 41 & 0.303 & 1865 & $\mathrm{Y}$ \\
\hline 2 & 09ES10 & 43 & 0.255 & 1868 & $\mathrm{Y}$ \\
\hline 2 & 09ES12 & 50 & 0.337 & 1858 & $\mathrm{Y}$ \\
\hline 3 & 09ES16 & 80 & 0.355 & 1849 & $\mathrm{Y}$ \\
\hline 4 & 09ES23 & 91 & 0.313 & 1863 & $\mathrm{Y}$ \\
\hline 4 & 09ES24 & 134 & 0.432 & 1862 & $\mathrm{Y}$ \\
\hline 4 & 09ES25 & 119 & 0.432 & 1865 & $\mathrm{Y}$ \\
\hline 4 & 09ES26 & 128 & 0.434 & 1863 & $\mathrm{Y}$ \\
\hline 5 & 09ES31 & 50 & 0.362 & 1867 & $\mathrm{Y}$ \\
\hline 5 & 09ES32 & 41 & 0.451 & 1858 & $\mathrm{Y}$ \\
\hline 6 & 09ES33 & 53 & 0.577 & 1861 & $\mathrm{Y}$ \\
\hline 6 & 09ES34 & 60 & 0.46 & 1863 & $\mathrm{Y}$ \\
\hline 6 & 09ES35 & 49 & 0.288 & 1867 & $\mathrm{Y}$ \\
\hline 7 & 09ES36 & 63 & 0.462 & 1867 & $\mathrm{Y}$ \\
\hline 7 & 09ES37 & 99 & 0.371 & 1861 & $\mathrm{Y}$ \\
\hline 7 & 09ES39 & 74 & 0.519 & 1862 & $\mathrm{Y}$ \\
\hline 7 & 09ES41 & 43 & 0.521 & 1861 & $\mathrm{Y}$ \\
\hline 8 & 09ES43 & 97 & 0.43 & 1861 & $\mathrm{Y}$ \\
\hline 8 & 09ES44 & 57 & 0.268 & 1857 & $\mathrm{Y}$ \\
\hline 8 & 09ES45 & 108 & 0.316 & 1862 & $\mathrm{~N}$ \\
\hline 9 & 09ES47 & 51 & 0.301 & 1862 & $\mathrm{Y}$ \\
\hline 10 & 08BDD3 & 135 & 0.484 & 1866 & $\mathrm{Y}$ \\
\hline 10 & 08BDD4 & 228 & 0.48 & 1868 & $\mathrm{Y}$ \\
\hline 10 & 08BDD5 & 226 & 0.443 & 1868 & $\mathrm{Y}$ \\
\hline 10 & 08BDD6 & 116 & 0.494 & 1868 & $\mathrm{Y}$ \\
\hline 10 & 08BDD7 & 136 & 0.499 & 1875 & $\mathrm{Y}$ \\
\hline 10 & 08BDD8 & 146 & 0.439 & 1874 & $\mathrm{~N}$ \\
\hline 10 & 08BD 9 & 127 & 0.444 & 1871 & $\mathrm{~N}$ \\
\hline 10 & 08BDD10 & 247 & 0.251 & 1875 & $\mathrm{Y}$ \\
\hline 10 & 08BDD11 & 108 & 0.5 & 1875 & $\mathrm{Y}$ \\
\hline 10 & 08BDD12 & 113 & 0.516 & 1875 & $\mathrm{~N}$ \\
\hline
\end{tabular}

Note: Sample correlations versus the master chronology are based on the mean of 50-year intervals, lagged by 25 years. Correlation values above 0.3281 are significant at the $99 \%$ confidence interval.

samples taken from the cliff to the master chronology is 0.412 (based on 50-year segments) when compared to the master chronology (Fig. 4). The results of this study provide strong dating of the timbers as a group, with $71 \%$ of the patterns of the samples being accurately dated at a $99 \%$ confidence interval.

\section{HISTORICAL VALIDATION OF RESULTS}

Our dating of the mine workings on the Fundy and Dirty seams can be validated against written documentation. Historical records show that the Fundy Seam was worked in the zone close to the cliff edge between 1731 and 1943, al- 
Table 1b. Samples from the Dirty Seam cross-dated against the Mount Allison Dendrochronology Laboratory (MAD Lab) regional red spruce master chronology.

\begin{tabular}{|c|c|c|c|c|c|}
\hline $\begin{array}{l}\text { Opening } \\
\text { number }\end{array}$ & $\begin{array}{l}\text { Sample identification } \\
\text { code }\end{array}$ & $\begin{array}{l}\text { Number of } \\
\text { tree-rings }\end{array}$ & $\begin{array}{l}\text { Mean correlation to } \\
\text { the master } \\
\text { chronology }\end{array}$ & $\begin{array}{l}\text { Last year } \\
\text { of growth }\end{array}$ & $\begin{array}{c}\text { Presence of } \\
\text { bark }(Y=y e s, \\
\mathrm{N}=\text { no })\end{array}$ \\
\hline 11 & 09ES28 & 48 & 0.324 & 1856 & $\mathrm{Y}$ \\
\hline 11 & 09ES29 & 33 & 0.352 & 1870 & $\mathrm{Y}$ \\
\hline 12 & 09ES40 & 43 & 0.369 & 1859 & $\mathrm{Y}$ \\
\hline 13 & 09ES48 & 82 & 0.389 & 1862 & $\mathrm{Y}$ \\
\hline 13 & 09ES49 & 110 & 0.345 & 1871 & $\mathrm{~N}$ \\
\hline 13 & 09ES51 & 63 & 0.435 & 1834 & $\mathrm{~N}$ \\
\hline 13 & 09ES52 & 130 & 0.462 & 1870 & $\mathrm{~N}$ \\
\hline 13 & 09ES54 & 112 & 0.446 & 1873 & $\mathrm{Y}$ \\
\hline 13 & 09ES55 & 141 & 0.531 & 1868 & $\mathrm{~N}$ \\
\hline 13 & 09ES56 & 99 & 0.439 & 1859 & $\mathrm{~N}$ \\
\hline 14 & 08BDD2 & 59 & 0.317 & 1869 & $\mathrm{Y}$ \\
\hline 14 & 08BDD13 & 133 & 0.413 & 1874 & $\mathrm{Y}$ \\
\hline 14 & 08BDD14 & 123 & 0.457 & 1870 & Y \\
\hline 14 & 08BDD16 & 71 & 0.248 & 1875 & $\mathrm{Y}$ \\
\hline 14 & 08BDD17 & 48 & 0.242 & 1867 & $\mathrm{Y}$ \\
\hline
\end{tabular}

Note: Sample correlations versus the master chronology are based on the mean of 50-year intervals, lagged by 25 years. Correlation values above 0.3281 are significant at the $99 \%$ confidence interval.

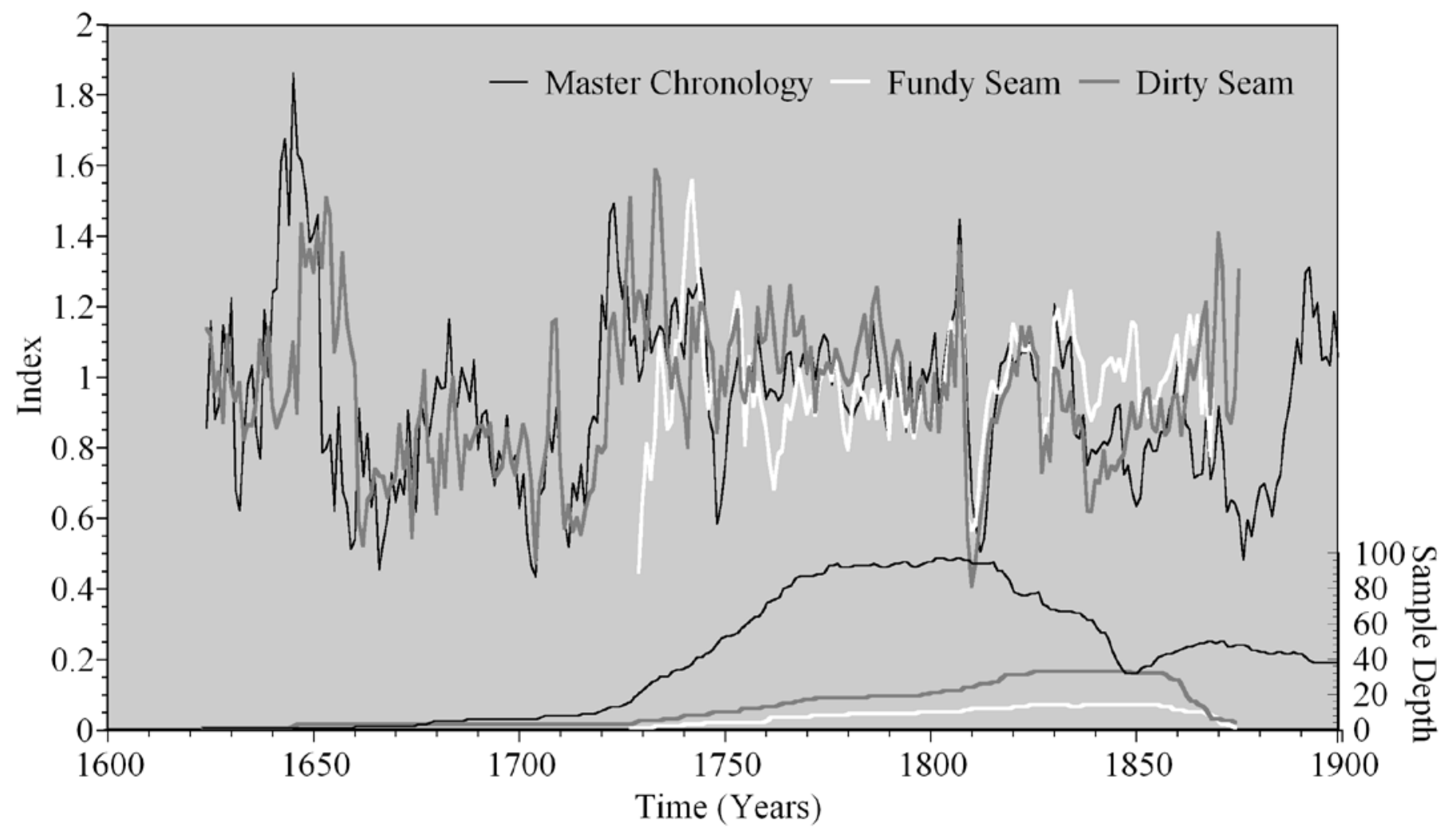

Fig. 4. A graph illustrating the standardized curves of the Fundy and Dirty seam floating chronologies compared to the master red spruce chronology and including sample depth. Each curve was standardized to have a mean of one; variations from the mean are deviations above and below average ring growth in each year. 
beit sporadically (Hale 1731; Drummond 1918; Goudge 1945; Copeland 1959; Falcon-Lang 2009). Dendrochronological studies presented here illustrate that the timber pit props currently exposed in the sea cliffs were cut between 1857 and 1875, with the exception of one sample dated to 1849 . This range of dates therefore allow us to focus on the historical accounts of Nineteenth Century mining activity on the Fundy Seam to test dates independently, and allows the archaeological record to be tied precisely with written documentation. This, in turn, provides additional information about the nature and timing of the coal mine workings preserved on the Fundy and Dirty seams.

In 1827, the General Mining Association (GMA) became "lessees of all the mines and minerals of every description in the province of Nova Scotia Proper" (Martin 1834, p. 105) and opened mines at Pictou and Sydney. However, it wasn't until 1847 that the GMA opened its first mine at Joggins (Anon 1848; Currie 1942). This mine exploited the Joggins Seam, which crops out $1 \mathrm{~km}$ south of our study site on the Fundy/ Dirty seams. The mine was set up at a cost of $£ 16,000$ and managed by Joseph Smith, who also ran the GMA mine at Pictou (Gesner 1849). An 1863 report indicates that the Joggins Seam was initially worked by driving an adit into the coal from its crop on the cliff (Currie 1942) but, soon after, it was worked by a 30-m-deep shaft sunk $\sim 80 \mathrm{~m}$ from the contemporaneous shoreline (Boggs 1871; Rutherford 1871) a little inland of the site of the present-day UNESCO centre (Falcon-Lang et al. 2010). Coal was brought to the surface using a horse-gin, carried down an inclined narrow-gauge railway to a pier on the shore near Bell's Brook, and loaded onto ships. Production increased from 2400 tons (1851) to 8478 tons (1866) during its initial operation, most of it being exported to Saint John, New Brunswick (Campbell 1871).

In 1857, the Nova Scotia government forced the GMA to give up most of its mineral rights in the province. However, the GMA retained control over the four-square-mile tract at Joggins (Brown 1899; Copeland 1959). In 1865, it expanded operations through the development of a drift mine on the Fundy and Dirty seams (Browne 1868). This was called the "New Mine" and was entered by an adit a few metres above the high water mark on shore (Dawson 1865, 1868). Coal was extracted through a series of slopes driven up-dip from horizontal levels to the crop-line on the cliff top (Hill 1888). Rutherford (1871, p.11), who was inspector of mines from 1865, described this GMA mine as follows: "The hard scrabble seam [=Fundy Seam] is entered by an adit in the cliff, and the coal is taken direct from the mine into a covered shed, out of which it is removed at a lower level, and carried along a wharf to the ships. This is but a temporary arrangement, but it is a very usual one on first opening mines similarly situated."

In 1871, the GMA abandoned the New Mine and sold this part of the Joggins tract to the Joggins Coal Mining Company (JCMC)(Drummond 1918). A report to the Nova Scotia House of Assembly indicates that the JCMC recommenced extraction of Fundy and Dirty seams through a slope mine opened in 1872 after a short lull in activity: "The Joggins Company have opened this colliery on the seam at Hard-scrabble [=Fundy Seam]. The slope has been started a third of a mile from the shore and driven down 270 feet, at which depth levels have been started to the right and left. An inclined tunnel 400 feet long, through the cliff, connects the mine with the wharf. The winding engine has two horizontal 11 inch cylinders, 30 inch stroke, and geared three to one to a drum 8 feet in diameter. The three boilers, 25 feet long and 2 feet 9 inches in diameter are hung from baulks of timber, and are all three fired together" (Drummond 1918, p. 34). This second mine was centred about $500 \mathrm{~m}$ east of the GMA mine, but its transport tunnel to the wharf on the shore, and associated levels, passed through the older GMA workings.

The history of the JCMC mine was short-lived. Operations had commenced at the height of a boom in the regional coal industry, triggered by the completion of the Truro-Moncton section of the Intercolonial Railway, in 1872. This railway, which ran through Maccan, less than 10 miles from Joggins, meant that coal could be used by coal-fired trains and easily transported to Halifax, although Saint John remained the main market. By this time, the Fundy Seam had acquired a particular "reputation as a superior coal for house purposes" (Boggs 1874 , p. 3) and was widely used in domestic hearths. Thus, when the Great Fire of Saint John (20 June 1877) drastically reduced local demand for domestic coal, the JCMC mine lost its principal market and closed (Brown 1899). From 1877 to 1903, no mines operated on the Fundy and Dirty seams at Joggins, all the work being centred on the Joggins Seam (Goudge 1945).

\section{Comparison of Dendrochronological and Historical Records}

Based on the historical record, the GMA and JCMC operations were the only mines working the Fundy and Dirty seams in the late Nineteenth Century, with coal extraction occurring in two well-constrained intervals, 1865-1871 and 1872-1877. These dates fit very closely with dendrochronological dates for the 48 pit samples in our study (1849-1875). Therefore, we confidently conclude that the coal mine workings exposed on the Fundy and Dirty seams today represent remains of the GMA and JCMC workings.

However, the coincidence of dates is not exact. Eighteen dates from samples with bark predate the operation of the New Mine including one for 1849 and a further 17 in the 18561863 interval. This may be explained by an earlier unreported period of mining on the Fundy and Dirty seams. However, this is unlikely; although the seams were sporadically mined in the Eighteenth (Hale 1731) and early Nineteenth century (Gesner 1836), detailed historical records give no hint of mining in the key period of interest, 1849-1863 (Gesner 1849; Brown 1899; Drummond 1918; Goudge 1945). A more likely explanation is that the workings were partly constructed from timber stockpiled or recycled from the adjacent Joggins Mine, which operated from 1847 (Gesner 1849). This would explain the quantities of timber incorporated in the New Mine with cut dates of 1849-1863, and we consider this to be the most 
likely hypothesis given that both mines were initially worked by the GMA.

Analysis of spatial patterns of the dendrochronological dates allows us to further discriminate between the two phases of mining on the Fundy and Dirty seams by the GMA and JCMC. As already noted, the GMA operation (1865-1871) mined from beach level upwards. Most openings currently exposed (numbers 1-9 and 11-12) represent a system of adits and associated levels with dates (1849-1868) consistent with this initial phase of drift mining (1865-1871). In contrast, the JCMC operation (1872-1877) was centred 500 m inland, but its access tunnel to the shore and associated working passed through the earlier GMA workings. Our dates for openings 10 and 13-14(1873-1875) suggest that these workings represent a system of levels at the western periphery of the JCMC operation. The prominent tunnel just above beach level, which climbs up-dip and has walls stained with ochre, may be the adit of the GMA drift mine or the access tunnel through which coal was transported from the JCMC mine to the wharf on the shore (Bell 1913; Drummond 1918).

As these entire coal mine workings are actively eroding into the Bay of Fundy, an unusual opportunity exists to monitor this site in future years. If further openings become exposed, it will be possible to continue to add to the dendrochronological record for the site and better constrain the timing and style of the two phases of mining. At the time of final sampling (2009), three clusters remained unsampled (see Fig. 3 ) and have the potential to provide further information. More research will further improve knowledge of the history of coal mining at the Joggins UNESCO World Heritage Site and provide valuable information for historians, conservationists and site managers.

\section{Refinement of regional master chronology}

The results of our work at Joggins are additionally important in that they allow the regional master chronology of red spruce to be refined. Now, the two floating chronologies can be added to the regional master and used to strengthen the sample depth of the existing regional master chronology to 1729 from samples obtained on the Fundy Seam, and to 1624 from the samples exposed on the Dirty Seam. This is valuable information, as trees over 100 years old are very difficult to find in this part of Atlantic Canada today due to extensive logging and human activities over the past 400 years. Every extra sample added to the master chronology gives more information on the growing environments of the trees of the region during historical time and can help to produce better paleoenvironmental reconstructions and provide further evidence for dendroarchaeological studies (e.g., Robichaud and Laroque 2008).

\section{CONCLUSIONS}

The cut dates of the timber samples currently exposed at the Joggins Fossil Cliffs (1849-1875) show a good correlation with the written record of mining activity at the site (1865-1877).
Our analysis allows identification of two phases of mining. Most of the openings currently exposed are relics of a GMA operation that mined up-dip from beach level from 1865 to 1871. A few other openings adjacent to a prominent tunnel at the base of the cliff represent levels of a later JCMC operation from 1872 to 1877 , which was centred $500 \mathrm{~m}$ inland, but whose access tunnel to the shore passed through the earlier GMA workings. A slight discrepancy between dendrochronological dates and those gleaned from the written archives may be resolved if the original GMA workings were constructed from timber stockpiled or recycled from the adjacent, but slightly older, Joggins Mine.

\section{ACKNOWLEDGEMENTS}

Financial assistance for fieldwork and analysis was granted by Natural Sciences and Engineering Research Council of Canada (NSERC) through Discovery Grants to Laroque and Gibling. Falcon-Lang acknowledges receipt of a NERC Advanced Fellowship. Special thanks go to the Joggins Fossil Centre for allowing use of their facilities during the research period and to members of the Mount Allison Dendrochronology Laboratory (MAD Lab), Carrie White, Ben Phillips, Felicia Pickard and Chris Kennedy, for their invaluable help during the sampling process. Critical reviews and suggestions by two anonymous reviewers and Brian Luckman, along with the journal editor, significantly improved the clarity and content of the manuscript.

\section{REFERENCES}

Anon. 1848. Coal! Coal! Coal! At the Joggins Mines. The British Colonist, August 5, 1848, Number 19, p. 3.

Bell, W.A. 1913. Excursion in eastern Quebec and the Maritimes Provinces; the Joggins section. Excursion Guide Book 1, XII International Geological Congress, Canada, pp. 326-346.

Boggs, R.B. 1871. Prospectus of the Joggins Coal Mining Company. Saint John, NB, 17 p.

Boggs, R.B. 1874. Prospectus of the Joggins Coal Mining Company. Saint John, NB, 12 p.

Brown, R. 1899. The coal fields and coal trade of the island of Cape Breton. Maritime Mining Record Office, Stellarton, N.S., 158 p.

Browne, J.R. 1868. On the mineral resources of the states and territories west of the Rocky Mountains. Government Printing Office, Washington, $240 \mathrm{p}$.

Calder, J.H., 1998. The Carboniferous evolution of Nova Scotia. In Lyell: The past is the key to the present. Edited by D.W. Blundell and A.C. Scott. Geological Society of London, Special Publication, 143, pp. 261-302.

Calder, J.H. 2006. 'Coal Age Galapagos': Joggins and the lions of Nineteenth Century geology. Atlantic Geology, pp. 42, 37-51.

Calder, J.H., Gibling, M.R., Scott, A.C., Davies, S.J., AND He- 
bert, B.L. 2006. A fossil lycopsid forest succession in the classic Joggins section of Nova Scotia: paleoecology of a disturbance-prone Pennsylvanian wetland. In Wetlands through time. Edited by S. Greb and W.A. DiMichele. Geological Society of America, Special Paper, 399, pp. 169-195.

Campbell, J. 1871. The Cumberland coal fields of Nova Scotia. Unpublished Report to the Proprietors, $8 \mathrm{p}$.

Cook, E.R. 1985. A time series analysis approach to tree ring standardization. Unpublished Ph.D. Dissertation, The University of Arizona, Tucson, $171 \mathrm{p}$.

Copeland, M. 1959. Coalfields, west half Cumberland County, N.S. Geological Survey of Canada, Memoir 298, 89 p.

Currie, L.D., 1942. Annual report on mines 1941, Department of Mines, Halifax, Nova Scotia. 183 p.

Davies, S.J., Gibling, M.R., Rygel, M.C., and Calder,J.H. 2005. The Joggins Formation: stratigraphic framework and sedimentological log of the historic fossil cliffs. Atlantic Geology, 41, pp. 115-141.

Dawson, J.W. 1865. On the conditions of the deposition of coal, more especially as illustrated by the coal formation of Nova Scotia and New Brunswick. Quarterly Journal of the Geological Society, London, 22, pp. 95-166. doi:10.1144/GSL. JGS.1866.022.01-02.12

Dawson, J.W. 1868. Acadian geology or the geology of Nova Scotia, New Brunswick and Prince Edward Island. 2nd edition. Oliver and Boyd, Edinburgh, 694 p.

Dawson, J.W. 1882. On the results of recent explorations of erect trees containing animal remains in the coal formation of Nova Scotia. Philosophical Transactions of the Royal Society, London 173, pp. pp. 621-659. doi:10.1098/ rstl.1882.0013

Drummond, R. 1918. Minerals and mining in Nova Scotia. Mining Record Office, Stellarton, $368 \mathrm{p}$.

Falcon-Lang, H.J. 2006. A history of research at the Joggins Fossil Cliffs, the world's finest Pennsylvanian section. Proceedings of the Geologists' Association, 117, pp. 377-392.

Falcon-Lang, H.J. 2009. The earliest history of coal mining and grindstone quarrying at Joggins, Nova Scotia and its implications for the meaning of the place-name "Joggins". Atlantic Geology, 45, pp. 1-21. doi:10.4138/atlgeol.2009.001

Falcon-Lang, H.J., Benton, M.J., Braddy, S.J., and Davies, S.J. 2006. The Pennsylvanian tropical biome reconstructed from the Joggins Formation of Canada. Journal of the Geological Society, London, 163, pp. 561-576. doi:10.1144/0016764905-063

Falcon-Lang, H.J., Gibling, M.R., and Grey, M. 2010. Classic localities explained 4: Joggins, Canada. Geology Today, 26, pp. 108-114. doi:10.1111/j.1365-2451.2010.00755.x

Franquelin, J-B. 1686. Chignitou: nommé depuis par les françois Beaubassin. Unpublished map. Archives du Hydrographique de la Marine, Paris.
Gesner, A. 1836. Remarks on the geology and mineralogy of Nova Scotia. Gossip and Coade, Halifax, 339 p.

Gesner, A. 1849. The industrial resources of Nova Scotia. A.C. MacKinlay, Halifax, 341 p.

Goudge, M.G. 1945. Joggins-River Hebert coal district (a review). Nova Scotia Department of Mines, Annual Report 1944, pp. 152-182.

Gresley, W.S. 1883. A glossary of terms used during coal mining. E. and F.N. Spon, London, 296 p.

Grissino-Mayer, H.D. 2001. Evaluating cross-dating accuracy: a manual and tutorial for the computer program COFECHA. Tree-Ring Research, 57, pp. 205-221.

Hale, R. 1731. Journal of a voyage to Nova Scotia made in 1731 by Robert Hale of Beverly. Reprinted in the Historical Collections of the Essex Institute, 42, pp. 217-243 (for 1906).

Hill, A.J. 1888. Report on sea area A-153, Joggins, Cumberland County, Nova Scotia. The Island Reporter Job Print, Sydney, 8 p.

Holmes, R. 1983. Computer-assisted quality control in treering dating and measurement. Tree-Ring Bulletin, 43, pp. 69-78.

Hower, J.C., Calder, J.H., Eble, C.F., Scott, A.C., Robertson, J.D., and Blanchard, L.J. 2000. Metalliferous coals of the Westphalian A Joggins Formation, Cumberland Basin, Nova Scotia, Canada: petrology, geochemistry, and palynology. International Journal of Coal Geology, 42, pp. 185206. doi:10.1016/S0166-5162(99)00039-7

Knox, J., George, A.D., Amherst, J., Amherst, W., Johnson, W., and Murray, J. 1759. A historical journal of the campaigns in North America, volume 1. Reprinted in 1914 by the Champlain Society, Toronto, $512 \mathrm{p}$.

Martin, R.M. 1834. The British Colonial Library, Volume 4. Bohn, London, $896 \mathrm{p}$.

Moll, H. 1730. A new and exact map of the dominions of the King of Great Britain on ye continent of North America containing Newfoundland, New Scotland, New England, New York, New Jersey, Pensilvania, Maryland, Virginia and Carolina. John Nicholson, London, scale 1:3 168000.

Robichaud, A., and Laroque, C.P. 2008. Dendroarchaeology in southwestern Nova Scotia and the construction of a regional red spruce chronology. Tree-Ring Research, 64, pp. 17-25. doi:10.3959/2007-9.1

Rutherford, J. 1871. Coal fields of Nova Scotia, Andrew Reid Publishers, London and Newcastle, $58 \mathrm{p}$.

Rygel, M.C., and Shipley, B.C. 2005. "Such a section as never was put together before": Logan, Dawson, Lyell, and midNineteenth-Century measurements of the Pennsylvanian Joggins section of Nova Scotia. Atlantic Geology, 41, pp. $87-102$.

Stokes, M.A., and Smiley, T. L. 1968. An Introduction to TreeRing Dating. University of Chicago Press, Chicago, 274 p.

Editorial responsibility: Robert A. Fensome 